\title{
Energy Ratio Factor and Phase Angle Based Fatigue Prediction Model for Flexible Pavements
}

\author{
Kim, Nakseok*
}

\begin{abstract}
The main objective of this research is to develop fatigue prediction model for flexible pavements using energy ratio factor and phase angle. The two parameters are considered as fundamental properties of time and temperature dependent viscoelastic asphalt concrete materials. The energy ratio factor is defined as the ratio of the pseudo-total cumulative dissipated energy to the cumulative dissipated energy to failure during the test. The phase angle between the stress and strain ware signals stems from the intrinsic the dependent asphalt mixture behavior. The phase angle was computed and the relationship between the initial mixture stiffness and the initial phase angle is presented. As a result, fatigue prediction model for flexible pavements was proposed using intrinsic properties of viscoelastic asphalt concrete materials.
\end{abstract}

Key words : Energy Ratio Factor, Phase Angle, Fatigue Prediction Model, Viscoelastic Materials

$$
\text { 요 지 }
$$

본 연구의 주목적은 에너지 비율 인자와 위상각을 이용한 연성포장의 피로예측 모델을 개발하는 것이다. 본 연구에서 도입된 에너지 비율 인자와 위상각은 점탄성 재료의 기본적인 성질을 반영하기 위하여 사용되었다. 에너지 비율 인자는 가상 방출 에 너지와 시험 중 파괴시 까지의 누적 방출 에너지의 비로 정의된다. 위상각은 아스팔트 혼합물의 응력과 변형률의 차이로부터 발생한다. 아스팔트 콘크리트 혼합물의 실험결과를 이용하여 위상각이 측정 되었으며 초기 stiffness와 초기 위상각의 관계가 제 시 되었다. 본 연구 결과 아스팔트 콘크리트 혼합물의 점탄성 재료라는 고유한 성질을 반영할 수 있는 에너지 비율 인자와 위 상각을 활용한 연성포장용 피로 예측 모델이 제안되었다.

핵심용어 : 에너지 비율 인자, 위상각, 피로 예측 모델, 점탄성 재료

\section{Introduction}

Some investigators(Chomton, G. et al., 1972; Havey, J., 1990) have recommended the recoverable strain of asphalt mixtures as a significant engineering parameter instead of the total initial tensile strain. The same approach is followed using the recoverable tensile strain at the 200th cycle in lieu of using initial tensile stress or strain in the ordinate of the plots. The linear behavior between the recoverable tensile strain and the fatigue life on a log-log scale generated the following power form of the fatigue model:

$$
N_{f}=K_{1}\left(\frac{1}{\varepsilon_{r}}\right)^{K_{2}}
$$

where $N_{f}=$ fatigue life

$\varepsilon_{r}=$ recoverable tensile strain

$K_{1}, K_{2}=$ experimentally determined regression constants
In 1985, Monismith et al. suggested the following mathematical relationship which is more applicable to asphaltaggregate mixtures in general:

$$
N_{f}=A\left(\frac{1}{\varepsilon_{l}}\right)^{b}\left(\frac{1}{S_{i}}\right)^{c}
$$

where $N_{f}=$ fatigue life

$\varepsilon_{i}=$ initial tensile strain,

$S_{i}=$ initial mixture stiffness

$A, b, c=$ experimentally determined regression constants

Many researchers(Kim, Y.R. et al., 1992; Monismith C.L. et al., 1985; Tayebali, A.A. et al., 1993) including Shell researchers, have performed the flexural beam fatigue test to characterize a given asphalt mixture using energy concepts. They used an energy approach for explaining fatigue behavior of the asphalt mixture and have shown that the total

*Member · Professor, Kyonggi University, Department of Civil Engneering (E-mail : nskim1@kgu.ac.kr) 
cumulative dissipated energy and fatigue life have the following relationship:

$$
W_{t}=A\left(N_{f}\right)^{Z}
$$

where $W_{t}=$ total cumulative dissipated energy

$N_{f}=$ fatigue life, and

$A, z=$ experimentally determined regression constants

It is noted that in Eq. (1) to (2) the fatigue life is described with the initial elastic material responses whereas in Eq. (3) the fatigue life is related with the overall viscoelastic material behaviors during the test. That is, the total cumulative dissipated energy is estimated from the fundamental stress and strain relationships with phase shifts from beginning to end. It is considered that the phase shifts between the stress and strain are an important engineering parameter in explaining the fatigue behavior of the timedependent and temperature-dependent viscoelastic asphalt mixtures. However, neither approach directly recognizes how damage to the mixture actually develops as loading accumulates during the fatigue test.

The main objectives of this research is to develop fatigue prediction model for flexible pavements using fundamental intrinsic properties of viscoelastic materials. Two parameters of energy ratio factor and phase angle are considered as fundamental properties of time and temperature dependent viscoelastic materials.

\section{Materials and Laboratory Testing Method}

Table 1 summarizes the asphalt cement properties tested separately by North Carolina State University and Blythe Industries, Inc., Staley, North Carolina. Also, the selected optimum asphalt contents of each asphalt concrete are presented in Table 2.

Table 1. Asphalt cement (AC-20) properties

\begin{tabular}{|c|c|c|}
\hline Properties & NCSU & Blythe Inc. \\
\hline $\begin{array}{c}\text { Absolute Viscosity } \\
\text { (poises) at } 60^{\circ} \mathrm{C}\end{array}$ & 1605.2 & 2153.7 \\
\hline $\begin{array}{c}\text { Kinematic Viscosity } \\
\text { (centistokes) at } 135^{\circ} \mathrm{C}\end{array}$ & 420.6 & 431.0 \\
\hline $\begin{array}{c}\text { Penetration }(0.1 \mathrm{~mm}) \\
\text { at } 25^{\circ} \mathrm{C}(100 \mathrm{gm}, 5 \mathrm{sec})\end{array}$ & 70.7 & 69.0 \\
\hline
\end{tabular}

Table 2. Selected optimum asphalt contents of each mixture

\begin{tabular}{|c|c|}
\hline Mixture Type & $\begin{array}{c}\text { Optimum Asphalt Content(\%) } \\
\text { (by weight of aggregate) }\end{array}$ \\
\hline Heavy Duty Surface (HDS) & 5.5 \\
\hline Heavy Duty Binder (HDS) & 4.7 \\
\hline Asphalt-Stabilized Base (HB) & 4.0 \\
\hline
\end{tabular}

\subsection{Aggregate}

The aggregates used in this research were \#67, \#467, \#78M, SCRG., and Sand. To get three type of mixtures (HDS, HBD, and HB), these aggregates were blended properly in certain proportions. The aggregate sourses and the selected blending proportions for each mixture are shown in Table 3. Also, the selected gradations of the three mixtures are presented in Table 4.

\subsection{Compaction}

The compaction efforts were adjusted based on the target air void content of the specimen. In this research, the target

Table 3. Aggregate Source and blending proportions for each mixture

\begin{tabular}{|c|c|c|c|}
\hline \multirow{2}{*}{ Mix Type } & \multicolumn{3}{|c|}{ Aggregate Source and blending Percentage (\%) } \\
\hline & Shipping Point & Materials & $\begin{array}{c}\text { Amount } \\
(\%)\end{array}$ \\
\hline \multirow{3}{*}{ HDS } & E.Forsyth Quarry & $\# 78 \mathrm{M}$ & 45.0 \\
\hline & E.Forsyth Quarry & SCRG. & 35.0 \\
\hline & Kelly Pit & Sand & 20.0 \\
\hline \multirow{3}{*}{ HDB } & E.Forsyth Quarry & $\# 67$ & 55.0 \\
\hline & E.Forsyth Quarry & SCRG. & 30.0 \\
\hline & Kelly Pit & Sand & 15.0 \\
\hline \multirow{3}{*}{$\mathrm{HB}$} & E.Forsyth Quarry & \#467 & 63.0 \\
\hline & E.Forsyth Quarry & SCRG. & 21.0 \\
\hline & Kelly Pit & Sand & 16.0 \\
\hline
\end{tabular}

Table 4. Selected aggregate gradations for each mixture

\begin{tabular}{|c|c|c|c|}
\hline \multirow{2}{*}{$\begin{array}{l}\text { Mix } \\
\text { Type }\end{array}$} & \multirow{2}{*}{$\begin{array}{l}\text { JMF Combined } \\
\text { Sieve Size }\end{array}$} & \multicolumn{2}{|c|}{ Percent Passing $(\%)$} \\
\hline & & NC Spec Limits & $\begin{array}{c}\text { Selected } \\
\text { Gradation }\end{array}$ \\
\hline \multirow{7}{*}{ HDS } & $19 \mathrm{~mm}$ & 100 & 100 \\
\hline & $13 \mathrm{~mm}$ & $96-100$ & 98 \\
\hline & $\# 4$ & $55-80$ & 67 \\
\hline & $\# 8$ & $40-60$ & 51 \\
\hline & $\# 40$ & $11-38$ & 25 \\
\hline & $\# 80$ & $4-20$ & 11 \\
\hline & $\# 200$ & $2-8$ & 4.1 \\
\hline \multirow{5}{*}{ HDB } & $25 \mathrm{~mm}$ & 100 & 100 \\
\hline & $19 \mathrm{~mm}$ & $90-100$ & 95 \\
\hline & $13 \mathrm{~mm}$ & $67-88$ & 77 \\
\hline & $\# 8$ & $25-45$ & 40 \\
\hline & $\# 200$ & $1-7$ & 4 \\
\hline \multirow{6}{*}{ HB } & $50 \mathrm{~mm}$ & & 100 \\
\hline & $38 \mathrm{~mm}$ & & 95 \\
\hline & $19 \mathrm{~mm}$ & & 75 \\
\hline & $\# 4$ & & 37 \\
\hline & $\# 8$ & & 33 \\
\hline & $\# 200$ & & 2.9 \\
\hline
\end{tabular}


air void content of the specimen was six percent with a WetWith-Parafilm(WWP) measurement procedure regard less of the specimen size or mixture type. This target air void content of the specimen was selected based upon the air void content measurements from the field core specimens. Generally, the air void contents from the field core specimens were in the wide range of four to eight percent.

\subsection{Air Void Content Measurement}

The air void content measurement was done in accordance with the new method, "Wet-With-Parafilm (WWP)" developed by the researchers at the University of California, Berkeley as a part of the SHRP Project A-003A. The maximum specific gravities of different asphalt concrete mixtures were measured at Blythe Industries, Inc. and are shown in Table 5. More detailed information and procedures for air void content measurement using parafilm can be found elsewhere(Chomton, G. et al., 1972; Havey, J., 1990; van Dijk, W. et al., 1977).

\subsection{Laboratory Testing Program and Data Acquisition}

The repeated load diametral fatigue test was selected and used to characterize fatigue properties of asphalt concrete due to its relative advantages. Also, test mode, type of specimen, and equipment are almost the same as those used in conventional resilient modulus tests and indirect tensile strength tests.

A servo-hydraulic system with a closed loop control was used in this research. Vertical loads and the corresponding horizontal displacements were measured by the load cell and extensometers, respectively, designed by MTS Systems Corporation. Test data of each channel were collected at the speed of 400/second (every 0.0025 second) over approximately five continuous cycles and by a data acquisition system with the multi-channel 12-bit board.

The haversine load with 0.05 second load duration and 0.45 second rest period was repeated until the specimen

Table 5. Maximum specific gravity of each mixture

\begin{tabular}{|c|c|}
\hline Mixture Type & Maximum Specific Gravity \\
\hline Heavy Duty Surface (HDS) & 2.51 \\
\hline Heavy Duty Binder (HDB) & 2.55 \\
\hline Asphalt-Stabilized Base (HB) & 2.55 \\
\hline
\end{tabular}

Table 6. Experimental design for fatigue characterization

\begin{tabular}{|c|c|c|c|}
\hline \multirow{2}{*}{ Temperature $\left({ }^{\circ} \mathrm{C}\right)$} & \multicolumn{3}{|c|}{ Mix Type } \\
\cline { 2 - 4 } & HDS & HDB & HB \\
\hline 0 & $\times$ & $\times$ & $\times$ \\
\hline 10 & $\times$ & $\times$ & $\times$ \\
\hline 20 & $\times$ & $\times$ & $\times$ \\
\hline
\end{tabular}

Three replications at least in each cell "failed." The stress amplitude was kept constant throughout testing, and time histories of horizontal and vertical deformations were recorded at the 200th cycle. Two load levels, low and high, were used which would induce the failure of the specimen under a given condition at about 100,000 and 10,000 cycles, respectively. Table 6 presents the experimental design.

\section{Development of Fatigue Prediction Model}

Many investigators (Kim, N., 2010; Tayebali, A.A. et al., 1993) including Shell researchers (van Dijk, W. et al., 1977) have suggested various performance prediction models with the application of the dissipated energy during the fatigue test. They have used an energy approach for describing fatigue behavior and have shown that the total cumulative dissipated energy to failure is related to the fatigue life. As a result, they have suggested Eq. (3).

In Eq. (3), the fatigue life is related to a terminal test condition, namely, the total cumulative dissipated energy. However, the main focus in this study is to express the fatigue life as a function of the initial engineering parameters instead of the total cumulative dissipated energy. That is, the fatigue life of an asphalt mixture can be described as a function of the initial terms including initial tensile strain. It is noted that this should be conducted without sacrificing the advantages of the total cumulative dissipated energy approach. Therefore, the following general derivations to express the fatigue life as a function of the initial engineering parameters are based on the previous research results conducted by several researchers including Shell investigators.

The dissipated energy per load repetition due to sinusoidal loading conditions can be expressed by:

$$
w_{n}=\frac{\pi}{4} \sigma_{n} \varepsilon_{n} \sin \left(\phi_{n}\right)
$$

or

$w_{n}=\frac{\pi}{4} \varepsilon_{n}^{2} S_{n} \sin \left(\phi_{n}\right)$

where $w_{n}=$ dissipated energy at load cycle $n$, $\sigma_{n}=$ stress amplitude at load cycle $n$, $\varepsilon_{n}=$ strain amplitude at load cycle $n$, $S_{n}=$ initial mixture stiffness at load cycle $n$, and $\phi_{n}=\begin{aligned} & \text { phase angle between the stress and strain wave } \\ & \text { signaals. }\end{aligned}$

The total cumulative dissipated energy obtained through the summation of the individual dissipated energy during the fatigue test is as follows:

$$
W_{t}=\sum_{n=1}^{n_{f}} W_{n}
$$


Assuming a controlled-dissipated energy test, the initial dissipated energy per load repetition $\left(w_{i}\right)$ remains constant during testing and the pseudo-total cumulative dissipated energy during the test can be described as follows:

$$
W_{p t}=w_{i} N_{f}
$$

or

$$
W_{p t}=\frac{\pi N_{f} \varepsilon_{i}^{2} S_{i} \sin \left(\phi_{i}\right)}{4}
$$

where $\quad w_{p t}=$ pseudo-total cumulative dissipated energy to failure,

$w_{i}=$ initial dissipated energy per load cycle, and

$N_{f}=$ number of load cycles to failure,

However, the controlled-stress or controlled-strain modes of testing are easily accessible rather than the controlledenergy mode of testing to perform fatigue tests. Despite the advancement in computer controlled testing and data acquisition systems, controlled-dissipated energy testing would be extremely difficult to conduct at this time. The stress or strain, the phase angle change, and the dissipated energy per cycle all change during the test. Therefore, a mode-of-loading dependent, energy ratio factor is introduced and defined as the ratio between the pseudo-total dissipated energy and the total cumulative dissipated energy:

$$
\psi=\frac{W_{p t}}{W_{t}}
$$

Substituting Eq. (3) and (8) into Eq. (9) yields:

$$
N_{f}=\left(\frac{4 A \psi}{\pi \varepsilon_{i}^{2} S_{i} \sin \phi}\right)^{\frac{1}{(1-z)}}
$$

and generalizing for the purpose of regression analysis:

$$
N_{f}=A(\psi)^{b}\left(\varepsilon_{i}\right)^{c}\left(S_{i}\right)^{d}\left(\sin \phi_{i}\right)^{e}
$$

However, additional two terms of the variables, initial air voids content $(\%)$ and testing temperature, were added to Eq. (11) since the fatigue performance of the asphalt concrete mixtures may not be fully explained with the engineering parameters described in Eq. (11). With the additional two terms, the following generalized regression equation is obtained:

$$
N_{f}=A(\psi)^{b}\left(\varepsilon_{i}\right)^{c}\left(S_{i}\right)^{d}\left(\sin \phi_{i}\right)^{e}\left(V_{i}\right)^{f}(T)^{g}
$$

The fatigue models estimated herein were based on Eq. (12). Based on Eq. (12), multi-regression analysis was conducted between the fatigue life and the initial laboratory testing parameters. The regression analysis yields the following relationships:

$$
\begin{aligned}
N_{f} & =6.23 \times 10^{-3}(\psi)^{1.363}\left(\varepsilon_{i}\right)^{-4.813}\left(S_{i}\right)^{-1.837}\left(\sin \phi_{i}\right)^{-0.902} \\
& =\exp \left(0.101 V_{i}-0.046 T\right) \\
N_{f} & =1.71 \times 10^{-7}(\psi)^{1.782}\left(\varepsilon_{i}\right)^{-4.601}\left(S_{i}\right)^{-1.082} \\
& =\exp \left(0.217 V_{i}-0.046 T\right) \\
N_{f} & =1.71 \times 10^{-7}(\psi)^{1.782}\left(\varepsilon_{i}\right)^{-4.601}\left(S_{i}^{\prime \prime}\right)^{-1.082} \\
& =\exp \left(0.217 V_{i}-0.046 T\right)
\end{aligned}
$$

where $N_{f}=$ fatigue life,

$\psi=$ energy ratio factor,

$\varepsilon_{i}=$ initial tensile strain,

$S_{i}^{\prime \prime}=$ initial stiffness (psi)

$S_{i}=$ loss modulus (psi)

$\phi_{i}=$ initial phase angle (degree)

$V_{i}=$ air void content $(\%)$, and

$T=$ temperture (degree, ${ }^{\circ} \mathrm{F}$ ).

The strain-dependent model, Eq. (13), requires the use of a multi-layered elastic system for the mechanistic analysis of in-situ pavement structures while the energy-dependent model, Eq. (15), requires energy-based viscoelastic analysis.

The following sections describe the general concepts of energy ratio factor and phase angle in more detail. In particular, the energy ratio factors and the phase angles were estimated from the controlled-stress diametral fatigue tests with three asphalt concrete mixtures.

\subsection{Energy Ratio Factor}

The energy ratio factor $(\psi)$ is defined as the ratio of the pseudo-total cumulative dissipated energy $\left(W_{p t}\right)$ to the total cumulative dissipated energy $\left(W_{t}\right)$ to failure during the test. The total cumulative dissipated energy to failure from the diametral fatigue test is the area under the number of cycles versus the dissipated energy shown in Fig. 1. The total cumulative dissipated energy to number of load repetitions to failure is determined by Eq. (6) while the pseudo-total cumulative dissipated energy is estimated with Eq. (7) or (8).

In this research, the energy ratio factor was estimated at different stiffnesses with three mixtures in the controlledstress diametral fatigue test. Generally, within the limitations of this research, the range of the energy ratio factor was in the range of 0.35 to 0.50 . Fig. 2 shows the relationship between the energy ratio factor and initial mixture stiffness for three mixtures (HDS, HDB, and HB).

It is noted that the energy ratio increased with increasing the initial stiffness in the controlled-stress diametral test. 


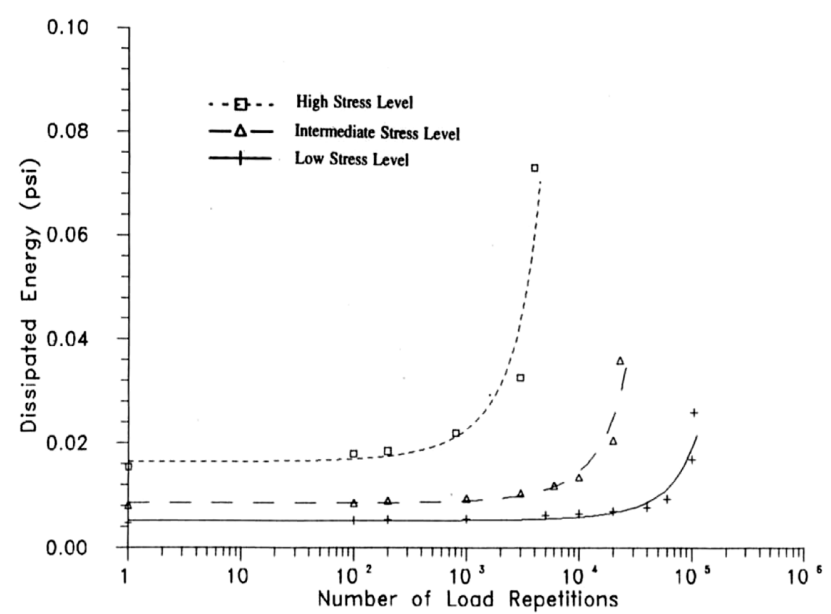

Fig. 1. Dissipated energy versus number of load repetitions in controlled-stress tests

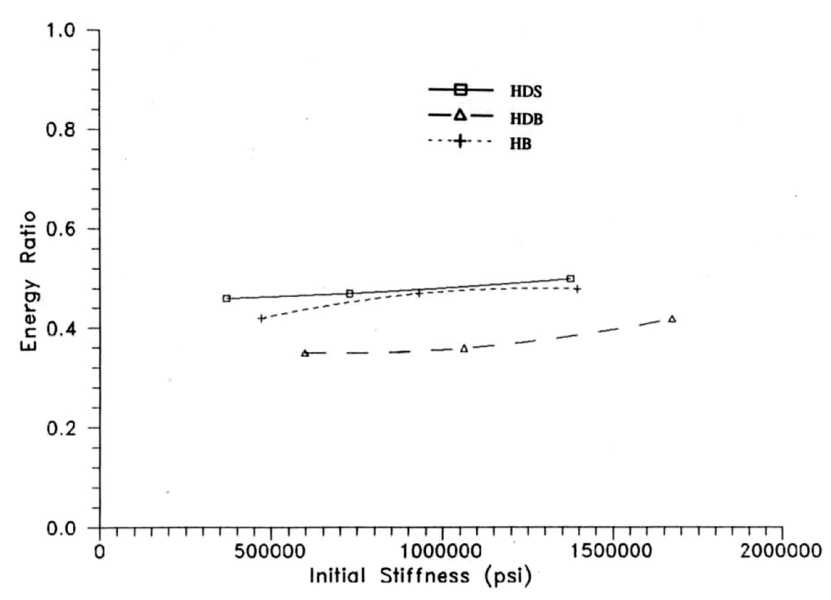

Fig. 2. Energy ratio factor $(\psi)$ versus initial mixture stiffness $\left(S_{i}\right)$

This finding is in good agreement with the research results reported by van Dijk and Visser(1977) that the energy ratio factor of the controlled-stress beam fatigue test increased with increasing initial stiffnesses.

\subsection{Phase Angle}

The phase angle is defined as the angle between the stress and strain wave signals at a certain load repetition. The phase angle between the stress and strain wave signals stems from the intrinsic time dependent asphalt mixture behavior. The phase angle is zero for a purely elastic material and 90 degrees for a purely viscous body.

However, at a fairly high stress level in the fatigue test, in the nonlinear viscoelastic range, it is considered that the phase angle results from the time dependency and the internal damage development of the asphalt specimen. In this research, the dissipated energy per cycle at a certain load repetition was computed using the area inside the hysteretic stress-strain loop(Kim, N., 2010). Also, the dissipated energy per load repetition due to the sinusoidal loading condition can be expressed by Eq. (5). Therefore, if the two equations equate each other, it generates the following relationship:



Fig. 3. Initial phase angle $\left(\phi_{i}\right)$ versus initial mixture stiffness $\left(S_{i}\right)$

$$
\phi_{i}=\sin ^{-1}\left(\frac{4 \int \delta d \varepsilon}{\pi \varepsilon_{i}^{2} S_{i}}\right)
$$

Based on this equation, the phase angle was computed and the relationship between the initial mixture stiffness and the initial phase angle is presented in Fig. 3. The figure shows that the phase angle decreased with increasing initial mixture stiffness. The same trend has been reported by van Dijk and Visser (van Dijk, W. et al., 1977) that the phase angle decreased with increasing initial stiffness in the controlledstress beam fatigue test.

\section{Conclusions}

Extensive laboratory material characterization tests were performed in this research. Within the limits of this study, the following primary conclusions can be drawn:

1) A fatigue prediction model for flexible pavements was developed using intrinsic properties(energy ratio factor and phase angle) of viscoelastic asphalt concrete materials.

2) The energy ratio factor $(\psi)$ is defined as the ratio of the pseudo-total cumulative dissipated energy $\left(W_{p t}\right)$ to the total cumulative dissipated energy $\left(W_{t}\right)$ to failure during the test. The range of the energy ratio factor for the asphalt concrete mixtures was in the range of 0.35 to 0.50 .

3) The phase angle results from the time dependency and the internal damage development of the asphalt specimen at a fairly high stress level in the fatigue test, in the nonlinear viscoelastic range.

\section{Acknowledgements}

This work was supported by Kyonggi University Research Grant 2010. 


\section{References}

Chomton, G. and Valayer, P.J. (1972) Applied Rheology of Asphalt Mixtures, Practical Applications, Proceeding Third International Conference on the Structural Design of Asphalt Pavements, London, Vol.I.

Havey, J. (1990) Asphalt Concrete Specimen Preparation Protocol SHRP Project A-OO3A, Technical Memorandum 90-4 Prepared for SHRP, Institute of Transportation Studies, University of California, Berkeley.

Kim, N. (2010) Development of Fatigue Performance Model of Asphalt Concrete using Dissipated Energy, Journal of the Korean Society of Hazard Mitigation, No.3, Vol. 10.

Kim, Y.R., Kim, N. and Khosla, N.P. (1992) Effect of Aggregate
Type and Gradation on Fatigue and Permanent Deformation of Asphalt Concrete, Published in 1992 ASTM STP 1147.

Monismith C.L., Epps, J.A. and Finn, F.N. (1985) Improve Asphalt Mix Design, Proceedings, Association of Asphalt Paving Technologists, Vol.54.

Tayebali, A.A., Deacon, J.A. and Monismith, C.L. (1993) Modeling Fatigue Response of Asphalt-Aggregate Mixtures, Proceedings, Association of Asphalt Paving Technologists.

van Dijk, W. and Visser, W. (1977) The Enery Approch to Fatigue for Pavement Design, Proceeding, Association of Asphalt Paving Technologists, Vol.44.

(9) 논문접수일 : 10년 12월 14일

() 심사의뢰일 : 10 년 12 월 14 일

() 심사완료일 : 10년 12월 24일 